\title{
A Review on the Effect of Self-congruity Dimensions on Customer's Switching Intention
}

\author{
Reza saleki ${ }^{1}$, Mohsen Saki ${ }^{2}$, Mohammad Javad Nekooei ${ }^{3 *}$ \\ 1,2 International Business School ,Universiti Teknologi Malaysia, Kuala Lumpur, Malaysia \\ ${ }^{3}$ Department of Mechanical Engineering, Safashahr branch, Islamic Azad University, Safashahr, Iran
}

\begin{abstract}
One of the new issues that marketers are facing is the effect of self-congruity on switching intention. The purpose of this study is to review the relationship among four dimensions of self-congruity (actual, ideal, social and ideal social congruity) and switching intention. This study only aims to review the former researches in examining the relationship among four dimensions of self-congruity and switching intention. The study has some recommendations and directions for the future studies. There are different variables such as geographical and psychological moderators that can moderate the relationship between self-congruity dimensions and switching intention. In the future, the researchers aim to collect the data by using survey questionnaires. The data will then be analyzed using statistical package for social science (SPSS). Pearson correlation coefficient, multiple and hierarchical regressions will be used in testing possible hypotheses.
\end{abstract}

Keywords: Self-congruity, Actual Ideal, Social and Ideal Social Congruity, Switching Intentions

\section{Introduction}

Two types of congruity were identified in previous studies: (i) self-congruity, which is highly related to knowledge of the congruity, and (ii) functional congruity, which is highly related to self-expressive features of the congruity (Hung and Petrick, 2011).

Kressmann et al. (2006) noted that in marketing context, self-congruity is known as the existed match among self-concept of the customers and perceived product image. Self-congruity hypotheses were examined in early investigation but the current studies try to employ more complicated self-congruity measures and to test them according to the impact of different elements like ownership, conspicuousness and the self-consciousness (Ross, 1971).

During the past few years, there was more understanding of significance for retain of the current consumers (Lewis, 2000). It was verified that the long term economic success of the firm is related positively to the repeat patronage because it causes lower marketing expenses, more sales and also more profitability for them (Lindgreen and Davis, 2000). Every industry with competitive nature does different attempts to get the repeat business. Decreasing the customer switching is currently as one of the important challenges for all industries, providing certain competitive advantages for them (Aad et al., 2008).

While the role of switching intention is quite apparent in marketing and consumer behaviors, rare studies in recent years have examined the relationship between self-congruity and switching intention (Han and Hyun, 2012). One of the contributions of this study, which makes it different from previous works, is that it reviews the relationship between all four dimensions of self-congruity (actual, ideal, social and ideal social selfcongruity) with switching intention while the previous studies only focused on the effect of only two dimensions of self-congruity on switching intention.

This study aims to answer the question on whether there is a negative significant relationship between four dimensions of self-congruity (actual, ideal, social and ideal social self-congruity) and switching intention. In addition, the study's objective is to review the relationship between four dimensions of self-congruity (actual, ideal, social and ideal social self-congruity) and switching intention.

From academic perspective, this study can broad the literature in the effect of self-congruity on switching intention and contributes to a growing body of research that examines the effect of self-image theory on switching intention. Furthermore, this study extends the body of knowledge of image congruity.

In overall, this work makes a new perspective in self-congruity theory for future studies by reviewing the relationship between four dimensions of self-congruity (actual, ideal, social and ideal social self-congruity) and switching intention.

\section{Literature Review}

This section consists of literatures, which are centered on the study variables, in order to develop a conceptual framework. In this study, the relevant literature was totally reviewed. This section consists of two main topics together with the subtopics as well. The main topics are as follows: switching intention, selfcongruity, and conceptual framework. Self-congruity has been divided into four subtopics including: (1) actual 
self-congruity (2) ideal self-congruity (3) social self-congruity (4) ideal social self-congruity. In this section, the relationship between self-congruity dimensions and switching intention is explained.

\section{Switching Intention}

Shen et al. (2006) explained switching intention as the fact that consumers prefer a service or product to the other one. Based on Jindal and Liu (2006), the customer switching is the destructive and active response for the dissatisfaction shown by the relationship break with a certain object. In addition, Ranaweera and Prabhu (2003) explained the customer switching as a decision for stopping the purchase of a certain service of a firm. Also, according to a research on consumer defection within banking industry, Worm et al. (2006) defined the defection or switch as the relationship ending between service provider and the customer.

\section{Self-congruity}

Self-congruity is the extension of mismatch or match among the individuals' perceptions of the brand and product (Sirgy, 1982). There are existed various definitions related to self-congruity. Holman (1980) noted that the self-image is the way individuals like to be seen. Jamal and Goode (2001) mentioned that same as individuals, all the products have their own personality images that are defined by price, physical aspects and advertisements. The product evaluation of the consumers is done by matching of the product image in opposite to her/his self-image and so the self-image congruity judgment will be developed (Johar and Sirgy, 1991). These days, the consumers more tend to buy specific products due to the symbolized meaning for them from those products. When customers enjoy a product, it means that they appreciate the product and so they are motivated about how they feel about themselves.

\section{Actual Self-congruity}

The impact of actual self-congruity on the customer behavior was recorded by many researches done in environment of retail stores and consumer goods. Within the consumer goods context, many studies tried to show the existed relationship between actual self-image and a product user image, provided a proper ownership or product (Sirgy et al., 1997). Within retailing, investigations from Dornoff and Tatham (1972), Babin and Attaway (2000), and Sirgy (1982) showed that there is a relationship between actual self-image and retail pattern image provided for a chosen store.

\section{Ideal Self-congruity}

The ideal self-congruity is the extent of match between retail pattern image and the ideal self-image of customer. The ideal self-image is a certain part of private self. An individual might see him/herself as timid and have little confidence but they still may not prefer the self-perception. They might want to be sensitive but at the same time self-assured. Like you might consider, always there is a discrepancy between ideal and actual ideal self. Ideal self-motivates attitude is related to the self-esteem need (Sirgy et al., 2000). Individuals have the ideal images for their own and understand the images by retail outlets and patronize stores which are related to them and might enhance their own self-esteem.

\section{Social Self-congruity}

The congruity of social self is the extent of existed match between a retail patron image and customer social self-image. The social self-image might be inconsistent or consistent with ideal and actual self. The social selfimage is a part of public self and not private self. The social self-image affects the behavior related to social consistency motive (Sirgy et al., 2000). Individuals will be motivated to keep the image other people have for them. So they do not feel comfortable if they function in ways that are not consistent with how they think other will see them. For instance, an individual might feel uncomfortable to visit a video store that rents some X-rated movies. The reason is they are scared to be seen by the people who know them. They think others will see them as a person quite reserved and not a sexual type individual.

\section{Ideal Social Self-congruity}

The ideal social self-congruity is the extent of the existed match between ideal social self-image of the customer and the retail patron image. Ideal social self-image like social self-image is a part of public self as well. Upscale clothing boutique's patrons might need to be observed by other people as classy. Therefore, their ideal social self-image is like this. Ideal social self-image can affect the individual's behavior by the motive of social approval (Johar and Sirgy, 1991).

\section{Relationship between Actual Self-congruity and Switching Intention}

Many experts in marketing and hospitality tried to study the important role of the self-congruity in defining the post purchase behavior of the customers (Back et al., 2005). Beginning in 1950s, the self-congruity theory 
was applied inside marketing area. Gardner and Levy (1955) studied the self-congruity theory related to customer behavior. They reviewed the impacts of brand meaning related to customers and showed that product's human aspects will respond highly to the psychological needs of consumers. Therefore, the first hypothesis is as follows:

H1: There is a negative significant relationship between actual self-congruity and switching intention.

\section{Relationship between Ideal Self-congruity and Switching Intention}

The impact of ideal self-congruity on the customer behavior was recorded by many studies conducted in the field of retail stores and consumer goods. Related to consumer goods, many investigations could show the availability of the relationship between ideal self-image and product user image, provided a suitable ownership or product (Malhotra, 1988). Related to retail evidence for the existed relationship it was developed by Sirgy (1980) and, Sirgy and Samli (1985). The second hypothesis is:

$\mathrm{H} 2$ : There is a negative significant relationship between ideal self-congruity and switching intention.

\section{Relationship between Social Self-congruity and Switching Intention}

The impact of social self-congruity on the customer behavior was recorded in many investigations developed in the field of retail stores and consumer products. Related to consumer products, many investigations have shown availability of relationship between the social self-image and the product user, developing a suitable ownership or product (Sirgy, 1982). In retailing, Sirgy and Samli (1985) and Sirgy et al. (1991), developed some proofs to show the impacts of socials self-congruity related to retail patronage. So, the third hypothesis would be:

H3: There is a negative significant relationship between social self-congruity and switching intention.

\section{Relationship between Ideal Social Self-congruity and Switching Intention}

The impact of ideal social self-congruity on customer behavior was recorded in many investigations conducted about the retail stores and consumer goods. Related to consumer products, many investigations shown that there is a relationship between the ideal social self-image and product user image which provides a proper ownership or product (Sirgy, 1982). Sirgy and Samli (1985) and Sirgy et al. (1991), have revealed impacts of ideal social self-congruity on retail patronage. Based on these studies, the fourth hypothesis is:

$\mathrm{H} 4$ : There is a negative significant relationship between ideal social self-congruity and switching intention.

\section{Conceptual Framework}

The conceptual framework shown in Figure 1 illustrates the relationships among study variables based on the previous researches that were discussed in the literature review. The framework reviews the links among self-congruity dimensions (actual, ideal, social and ideal social congruity) and switching intention.

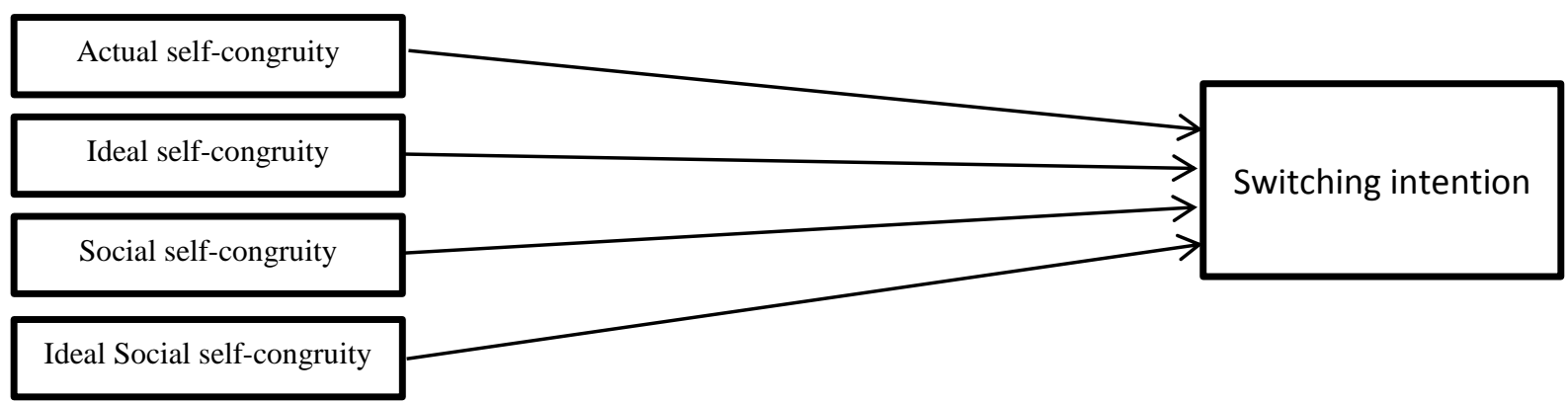

Self-congruity Dimensions

Figure 1: Conceptual Framework

This section briefly discussed the relevant literature pertaining to the study variables and designed the formulation of the research structure. Five variables namely switching intention, actual self-congruity, ideal selfcongruity, social self-congruity and ideal social self-congruity were clarified in this section.

\section{Methodology}

Choosing the correct methodology process for searching the information on literature review is an important aspect in the study. It helps to understand, widen or enhance the knowledge related the subject matters discussed in this study. The correct design of methodology used not only to carry the project study process smoothly and effectively but also to obtain and achieve its objectives. 
The main purpose of this study is to review the relationship between self-congruity dimensions (actual, ideal, social and ideal social congruity) and switching intention. In this section, methodology, which has been used to conduct this research, is explained comprehensively.

\section{Research Design}

According to Boyer et al. (2005), a research design is the detailed blueprint that acts as guidance in a research study towards its objectives. The present study will follow positivist paradigm and then utilize quantitative method. According to Maiyaki and Mokhtar (2010), a descriptive research is a research that examines the characteristics of a sample of population of people who have influences on the background of the problems. The present study also will follow the suit. This study plans to adopt survey approach for collecting the data in the future. The researcher will use quantitative method in designing questionnaires, sampling and also to translate numerical data from questionnaires into significant narrative information as suggested by Pasternack et al. (2008).

\section{Variables and Measures}

The research framework consists of five variables among which four are independent variables and one dependent variable. Independent variables consist of actual self-congruity, ideal self-congruity, social selfcongruity and ideal social self-congruity. Dependent variable is switching intention. In the following lines, each variable measurement is explained comprehensively.

\section{Dependent Variable}

Switching Intention

Items for measuring switching intention will be adapted from Chih et al. (2012). The scale is consisted of four items. Seven point likert scale will be used which measured from 1 = "strongly disagree" to 7 = "strongly agree". Table 3.1 shows items for measuring the switching intention variable.

Table 3.1: Measurement items of switching intention

\begin{tabular}{|l|l|l|}
\hline \multicolumn{1}{|c|}{$\begin{array}{l}\text { Switching Intention } \\
\text { Definition: Switching intention refers to propensity to terminate the primary supplier (buyer-seller) } \\
\text { relationship. }\end{array}$} & Source \\
\hline No & \multicolumn{1}{|c|}{ Items } & Chih et al. \\
\hline 1. & In the near future, I intend to intensify my efforts to find a better hotel. & (2012) \\
\hline 2. & In the last year, I have considered seriously switch to other hotels. & \\
\hline 3. & I have decided to stay less in this hotel in the future. & \\
\hline 4 & I think other hotels can offer better service. & \\
\hline
\end{tabular}

\section{Independent Variable}

\section{Self-congruity Dimensions}

In this research, key measurements of constructs are borrowed from the past studies. It will try to employ one of the two main approaches for measuring the self-congruity (Sirgy et al., 1997). First approach will employ a formula of gap scoring in order to compete with the self-concept and perceived image of product measurement (Johar and Sirgy, 1991). Next approach will capture directly the self-congruence measures. It tries to be highly valid and also predictive for evaluating the consumer behavior (Kressmann et al., 2006). This research will use the second approach for measuring the ideal, actual, ideal social and social self-congruity. The self-congruity will be assessed by using scenario direction and twelve statements of self-congruence. The mentioned variables use a seven point rating scale which ranges from $1=$ "strongly disagree" to $7=$ "strongly agree". Future participants will all be instructed for responding the statements of self-congruent.

Items for measuring actual and ideal self-congruity will be adapted from Sirgy and Su (2000). For measuring social and ideal social self-congruity items will be adapted from Han and Hyun (2012). Table 3.2 shows the items for dimensions of self-congruity.

Table 3.2: Measurement items of self-congruity dimensions

\begin{tabular}{|c|c|c|}
\hline \multicolumn{3}{|c|}{ Definition: Actual self-congruity refers to how people see themselves. } \\
\hline No & Item & Source \\
\hline 1. & The image of the typical customer of this hotel is similar to how I am. & \multirow{3}{*}{$\begin{array}{l}\text { Sirgy and Su } \\
(2000)\end{array}$} \\
\hline 2. & The image of the typical customer of this hotel is similar to how I see myself. & \\
\hline 3. & $\begin{array}{l}\text { The image of the typical customer of this hotel is similar to how others believe that I } \\
\text { am. }\end{array}$ & \\
\hline
\end{tabular}




\begin{tabular}{|c|c|c|}
\hline 4. & The image of the typical customer of this hotel is similar to how others see me. & \\
\hline & $\begin{array}{l}\underline{\text { Ideal Self-congruity }} \\
\text { Definition: Ideal self-congruity refers to how people would like to see themselves. }\end{array}$ & \multirow{5}{*}{$\begin{array}{l}\text { Sirgy and } \mathrm{Su} \\
(2000)\end{array}$} \\
\hline 5. & "The image of the typical customer of this hotel is similar to how I would like to be". & \\
\hline 6. & $\begin{array}{l}\text { "The image of the typical customer of this hotel is similar to how I would like to see } \\
\text { myself." }\end{array}$ & \\
\hline 7. & $\begin{array}{l}\text { "The image of the typical customer of this hotel is similar to how I would like others to } \\
\text { see me." }\end{array}$ & \\
\hline \multirow[t]{2}{*}{8.} & $\begin{array}{l}\text { "The image of the typical customer of this hotel is similar to how I ideally like to be } \\
\text { seen by others." }\end{array}$ & \\
\hline & $\begin{array}{l}\text { Social Self-congruity } \\
\text { Definition: Social self-congruity refers to how people think others see themselves. }\end{array}$ & \multirow[t]{2}{*}{$\begin{array}{l}\text { Han and Hyun } \\
(2012)\end{array}$} \\
\hline \multirow[t]{2}{*}{9.} & The image of the typical customer of this hotel is similar to how I am. & \\
\hline & $\begin{array}{l}\text { Ideal Social Self-congruity } \\
\begin{array}{l}\text { Definition: Ideal social self-congruity refers to how people would like others to see } \\
\text { themselves. }\end{array}\end{array}$ & \multirow[t]{4}{*}{$\begin{array}{l}\text { Han and Hyun } \\
(2012)\end{array}$} \\
\hline 10. & $\begin{array}{l}\text { "The typical customer at this restaurant has personality characteristics similar to mine } \\
\text { as perceived by others." }\end{array}$ & \\
\hline 11. & $\begin{array}{l}\text { "The typical customer at this restaurant has an image similar to how I would like other } \\
\text { people to see me." }\end{array}$ & \\
\hline 12. & $\begin{array}{l}\text { "The typical customer at this restaurant is very much the kind of person I would like } \\
\text { other people see me as." }\end{array}$ & \\
\hline
\end{tabular}

\section{Questionnaire Design}

The questionnaire will be consisted of two sections and each section will measure respondents' ideas and perceptions towards each variable studied. Section A, will consist of twelve questions for measuring respondents' opinions toward self-congruity dimension (actual self-congruity, ideal self-congruity, social selfcongruity and ideal social self-congruity). This section will consist of four questions for actual self-congruity, four questions for ideal self-congruity, one question for social self-congruity and three questions for ideal social self-congruity. Section B will consist of six questions to discover the respondents' opinions toward switching intention. Both sections will use a seven point Likert scales from strongly disagree to strongly agree.

\section{Future Work}

This study reviews the relationship between four dimensions of self-congruity (actual, ideal, social and ideal social self-congruity) and switching intention. This study has some recommendations and directions for the future studies. There are different variables such as geographical and psychological moderators that can moderate the relationship between self-congruity dimensions and switching intention. Future studies are advised to use switching cost and customer involvement variables as moderators in their theoretical model. This study also measures self-congruity dimensions directly, using the global measurement method developed by Sirgy et al. (1997). However, there has been a considerable debate over whether to use the direct score formula or gap score formula in measuring self-congruity dimensions. Future research could measure self-congruity by using the gap score formula or could employ both the direct score and gap score formulas and compare the upcoming results.

\section{Reference}

[1]. Babin, B. J., and Attaway, J. S. (2000). Atmospheric affect as a tool for creating value and gaining share of customer. Journal of Business Research. 49(2), 91-99.

[2]. Back, B., Baker, M., Ballintijn, M., Barton, D., Becker, B., Betts, R., et al. (2005). The PHOBOS perspective on discoveries at RHIC. Nuclear Physics A. 757(1), 28-101.

[3]. Boyer, L. A., Lee, T. I., Cole, M. F., Johnstone, S. E., Levine, S. S., Zucker, J. P., et al. (2005). Core transcriptional regulatory circuitry in human embryonic stem cells. Cell. 122(6), 947-956.

[4]. Chih, W.-H., Wang, K.-Y., Hsu, L.-C., and Cheng, I.-S. (2012). From disconfirmation to switching: an empirical investigation of switching intentions after service failure and recovery. The Service Industries Journal. 32(8), 1305-1321.

[5]. Dornoff, R. J., and Tatham, R. L. (1972). Congruence between personal image and store image. Journal of the Market Research Society.

[6]. Gardner, B. B., and Levy, S. J. (1955). The product and the brand. Harvard Business Review. 33(2), 33-39.

[7]. Han, H., and Hyun, S. S. (2012). Image congruence and relationship quality in predicting switching intention: Conspicuousness of product use as a moderator variable. Journal of Hospitality \& Tourism Research.

[8]. Holman, R. H. (1980). A sociological approach to brand choice: the concept of situational self image. Advances in consumer research. 7, 610-614.

[9]. Hung, K., and Petrick, J. F. (2011). Why do you cruise? Exploring the motivations for taking cruise holidays, and the construction of a cruising motivation scale. Tourism Management. 32(2), 386-393.

[10]. Jamal, A., and Goode, M. M. (2001). Consumers and brands: a study of the impact of self-image congruence on brand preference and satisfaction. Marketing Intelligence \& Planning. 19(7), 482-492.

[11]. Jindal, N., and Liu, B. (2006). Mining comparative sentences and relations. AAAI. 1331-1336. 
[12]. Johar, J. S., and Sirgy, M. J. (1991). Value-expressive versus utilitarian advertising appeals: when and why to use which appeal. Journal of advertising. 20(3), 23-33.

[13]. Kaveh, J., and Saleki, R. (2013). New Brand Creation and Power of Alliance Strategy. Australian Journal of Basic \& Applied Sciences. 7(8).

[14]. Kressmann, F., Sirgy, M. J., Herrmann, A., Huber, F., Huber, S., and Lee, D.-J. (2006). Direct and indirect effects of self-image congruence on brand loyalty. Journal of Business Research. 59(9), 955-964.

[15]. Lindgreen, A., Davis, R., Brodie, R. J., and Buchanan-Oliver, M. (2000). Pluralism in contemporary marketing practices. International Journal of Bank Marketing. 18(6), 294-308.

[16]. Malhotra, N. K. (1988). Self concept and product choice: an integrated perspective. Journal of Economic Psychology. 9(1), 1-28.

[17]. Pasternack, S. M., von Kügelgen, I., Al Aboud, K., Lee, Y.-A., Rüschendorf, F., Voss, K., et al. (2008). G protein-coupled receptor P2Y5 and its ligand LPA are involved in maintenance of human hair growth. Nature genetics. 40(3), 329-334.

[18]. Ranaweera, C., and Prabhu, J. (2003). The influence of satisfaction, trust and switching barriers on customer retention in a continuous purchasing setting. International Journal of Service Industry Management. 14(4), 374-395.

[19]. Shen, D., Laffey, J., Lin, Y., and Huang, X. (2006). Social influence for perceived usefulness and ease-of-use of course delivery systems. Journal of Interactive Online Learning. 5(3), 270-282.

[20]. Saleki, R. (2014). Assessing the effect of self-congruity and functional congruity on switching intention in Malaysian hotel industry. Unpublished Master thesis. Universiti Teknologi Malaysia.

[21]. Saleki, R., Saki, M., and Nikkhah, H. (2013). Investigating effect of self-image on customer's attitude in Malaysian restaurant industry. European Journal of Scientific Research. 162(5), 328-349.

[22]. Sirgy, M. J. (1980). Self-concept in relation to product preference and purchase intention. Developments in marketing science. 3(2), 350-354.

[23]. Sirgy, M. J. (1982). Self-concept in consumer behavior: A critical review. Journal of consumer research, 287-300.

[24]. Sirgy, M. J., and Cornwell, T. (2001). Further validation of the Sirgy et al.'s measure of community quality of life. Social Indicators Research. 56(2), 125-143.

[25]. Sirgy, M. J., Grewal, D., and Mangleburg, T. (2000). Retail environment, self-congruity, and retail patronage: an integrative model and a research agenda. Journal of Business Research. 49(2), 127-138.

[26]. Sirgy, M. J., Grewal, D., Mangleburg, T. F., Park, J.-o., Chon, K.-S., Claiborne, C., et al. (1997). Assessing the predictive validity of two methods of measuring self-image congruence. Journal of the academy of marketing science. 25(3), $229-241$.

[27]. Sirgy, M. J., Johar, J., Samli, A. C., and Claiborne, C. (1991). Self-congruity versus functional congruity: predictors of consumer behavior. Journal of the Academy of Marketing Science. 19(4), 363-375.

[28]. Sirgy, M. J., and Samli, A. C. (1985). A path analytic model of store loyalty involving self-concept, store image, geographic loyalty, and socioeconomic status. Journal of the Academy of Marketing Science. 13(3), 265-291.

[29]. Sirgy, M. J., and Su, C. (2000). Destination image, self-congruity, and travel behavior: Toward an integrative model. Journal of Travel Research. 38(4), 340-352.

[30]. Worm, B., Barbier, E. B., Beaumont, N., Duffy, J. E., Folke, C., Halpern, B. S., et al. (2006). Impacts of biodiversity loss on ocean ecosystem services. science. 314(5800), 787-790. 